\title{
街星写克から世界遗産の 3D 模型化の試み Attempts to 3D Modelling of World Heritages
}

\author{
山島一浩 ${ }^{1 *}$ \\ Kazuhiro YAMASHIMA ${ }^{1 *}$
}

1 筑波学院大学
Tsukuba Gakuin University

世界遺産シーギリヤ(スリランカ)について, ALOSグローバルデジタルサーフェスモデルを使用し て3Dプリンターで印刷した. スリランカには, 多くの歴史的・文化的地点があることを踏まえ, このデ 一タを用いて世界遺産のモデリングの実現可能性を探った. PRISMによる世界デジタル表面モデ ルの分解能 $30 \mathrm{~m}$ (1 arcese) のデータセットです.このデータセットは, 世界最高の精度を有するデジ タル 3D地形データのDSMデータセット (5m分解能)に基づいて作成された標高データセットです. TIFF画像の形式のこのデータは, プログラムによって 3Dプリンタ用の 2D画像から 3D STLデータに 変換される. その際, まず, $3600 \times 3600$ 画素, 16 ビットのTIFF画像から, 世界遺産に必要な部分を 抽出する. そして, 抽出した画像をSTLデータに変換し, 印刷出力する.

I have printed out models of the world heritages in Sri Lanka with a 3D printer by using the ALOS global digital surface model (DSM) "ALOS World 3D - 30m. Noting that Sri Lanka under such remarkable economic and social development also has many historical and cultural sites, we explored the feasibility of modelling the world heritages by using this data. The ALOS global digital surface model is open to the public at free by JAXA for the sake of the scientific research fields and utilization of the geospatial information. This is a data set of $30 \mathrm{~m}$ (1arcese) resolution of the global digital surface model (DSM) by the Panchromatic Remote-sensing Instrument for Stereo Mapping (PRISM) mounted on the advanced land observing satellite "ALOS". This data set was created based on the DSM data set (5m resolution) of the "world digital 3D topographic data", which has the world best accuracy at present as a global-size elevation dataset. This data in the form of TIFF images is converted from the 2D images to 3D STL data for 3D printers by a program. In doing this, firstly, the portions necessary for the world heritages are extracted from the TIFF images stored at $3600 \times$ 3600pixels with 16 bits. Then, the extracted images are converted into the STL data, which is then printed out by the 3D printer. The output data is exhibited and released on Web.

キーワード: 世界遺産,Stereolithography, GeoTIFF 


\section{1 はじめに}

スリランカは，多くの歴史的・文化的 地点があることを踏まえ，このデータを 用いて世界遺産のモデリングの実現可能 性を探ろうと考えた。

スリランカの世界遺産のモデルをALOS グローバルデジタルサーフェスモデルを 使用して3Dプリンターで印刷した。その 過程に伴った議論を提示したい.

\section{2 シーギリヤの歴史}

スリランカのシーギリヤは, 中部のマータ レーにある古都である. シーギリヤは, 5 世 紀, シン八ラ王朝のカーシャパ王 (在位 477 〜45 年)によって建設された王都でもあっ た.

巨大な岩であるシーギリヤ・ロックには， 岩の上にある王宮跡と, 麓の水路, 庭園, 貯蔵施設などの施設で構成される. 頂上の 面積は 1.6 ヘクタールもあり, 王宮や住居, 沐浴場などが残されている.

シーギリヤに王都を建てたカーシャパ王 は, タミル人からシンハラ人に王権を取り戻 したダートゥセーナ王の息子である. カーシ ヤパは, 甥であり軍司令官でもあったミガラ の支援を得て, クーデターをおこし, 王権を 篡奪した.

カーシャパ王は, 弟にモッガラーナがい た. カーシャパ王は, モッガラーナに王位を 奪還されることを恐れ，長らく首都であった アヌラーダプラを離れ，王都を移した. シー ギリヤ・ロックに王宮が完成したのは, 484 年 のことである.
その 11 年後, モッガラーナはカーシャパ 王に戦いを挑み, 495 年, 劣勢になった力 ーシャパ王は, 自害した.

王権を奪取したモッガラーナ王は, 都を かつてのアヌラーダプラに戻し, シーギリヤ は, 仏教僧に寄進された. 14 世紀頃まで修 道院として使われていたが, その後放棄さ れる。

そして,イギリス統治時代の 1857 年に発 見され，再び人々に知られることになった。

\section{3 デジタル 3D地図とは}

\section{1 地理空間情報}

日本国内の地理空間情報は, 地理空間 情報活用推進基本法に定義されるものを指 す.つまり，空間上の特定の地点又は区域 の位置を示す情報や，その情報に関連付 けられた情報となる. また地球上の位置だ けでなく, 時間軸上の位置も対象となる.

\section{2 デジタル 3D地図}

デジタル 3D地図とは, 地表の水平位置 と高さの 3 次元座標值が記録されたデー タのことである. 高さを示す数值標高モ デルと，水平位置を示す正射投影画像の 2 種類のデータで構成される，正射投影 画像とは，上空から撮影された画像の地 形にともなう歪みを除去し，位置情報が 付与されたものである.

今回用いたデジタル 3D地図の数值標高 モデルは，PRISMが取得した画像の中か ら雲が少ない約 300 万枚を活用して，5m の水平解像度という細かさと, $5 \mathrm{~m}$ の高さ 精度（標準偏差）で，陸地の起伏を表現 したものである. 
PRISMによる世界デジタル表面モデル の分解能 $30 \mathrm{~m}$ (1 arcese) のデータセット である.このデータセットは，5m分解能 のDSMデータセットである.

それは, GeoTIFFで記録されている.

\subsection{GeoTIFFの構成}

\subsubsection{TIFF}

TIFFは, ビットマップ画像の符号化形式の 一種である. タグと呼ばれる識別子を使うこ とによって, 様々な形式のビットマップ画像 を柔軟に表現できる.

TIFF形式は, 汎用ラスタデータ形式で, ク リップアート, ロゴタイプ, スキャンされたドキ ユメントなどのラスタイメージの保存, 転送, 表示, および印刷に適したフォーマットであ る.

TIFFは, ラスターイメージを格納および交 換するためのタグベースのファイル形式で す. TIFFは, ラスターイメージデータを記述 して保存する.

TIFFの主な利点は, 幅広いアプリケーシ ヨンとコンピュータのアーキテクチャ, オペレ ーティングシステム, およびグラフィックスハ ードウェアの独立性に適している.

それは, 合理的にコンパクトで, 白黒, グ レースケール，およびカラー画像を扱うこと ができ, スキャナ，モニタ，またはプリンタの 固有の特性を調整することができる.

TIFFでは, フルRGBカラーまたは 64kカラ ーパレットのいずれかで, 最大 48 ビット $(\mathrm{R}$, $\mathrm{G}$, およびBの各 16 ビットフィールド)のカラ 一解像度が可能である.

画像データを, 解像度や色数, 符号化方 式が異なるものでも様々な形式で一つのフ アイルにまとめて格納できるため, アプリケ ーションソフトに依存することがあまり無いフ
オーマットであると言える.

自由度の高い表現が可能なので, 完全な 互換性を保つことが難しくなっている.

TIFFの規約もすべてのタグをサポートす る必要はないと明記している.

\subsubsection{GeoTIFFの基本機能}

GeoTIFFは, 地理参照情報をTIFFファイ ルに埋め込むことを可能にするパブリックド メインのメタデータ標準です. GeoTIFFは, TIFF画像ファイルフォーマットで, デジタル 衛星画像, 航空写真, 標高モデルで使用さ れている.

GeoTIFFファイルの地理データを使用して, 地理情報ディスプレイの画面上の正しい位 置とジオメトリに画像を配置することができる. さまざまなGISパッケージで簡単にデジタル 衛星画像を保存するためにTIFF形式を使 用していた。

GeoTIFFは, タグ付き画像ファイル形式フ アイルに地理参照情報が埋め込まれてい る.GeoTIFF形式は, TIFF 6.0 に完全に準 拠している. それ故, 拡張機能は, TIFFが サポートするラスタデータの範囲を制限しな い.

つまり, タグのセットを使用して, 広範囲 のジオリファレンス情報を格納し, 地理座標 系と投影座標系のニーズに対応させてい る.

投影方法 (地図), 座標, 楕円, 測地系な どの正確な位置情報を参照する必要性に 忘じた情報が追加されている.

投影には, UTM, 米国国家平面, ナショナ ルグリッド, Transverse Mercator, Lambert Conformal Conicなどの基本投影タイプがあ る. 


\subsection{3 座標変換}

GeoTIFFの目的は, ラスタデータセット内の 地理参照された場所の明確な識別を可能 にすることである.

GeoTIFF命名法では,「ジオリファレンス」 とはラスタ空間をモデル空間に結びつける ことを指し，「ジオコーディング」は，モデル 空間がどのように地球上の点に座標を割り 当てるかを定義することを指す。

ほとんどの場合, モデル空間は 2 次元の みであり, その場合，KとZの両方をゼロに設 定する必要がある.この第 3 の次元は, 3D デジタル標高モデルおよび垂直座標系に 対する将来のサポートを予期して提供され る.

\subsubsection{GISとGeoTIFF}

GeoTIFFは, 衛星画像データユーザーの 間では事実上の標準になっている. GeoTIFFをサポートするほとんどすべ ての標準GISおよびImage Processingパ ッケージは，世界中のさまざまなGISア プリケーションの標準イメージファイル 形式である。

\section{4 三次元形状を表現するデータ}

\subsection{3次元データムファイル交換}

3 次元形状の表現には, stl形式がある. 三次元形状を小さな三角形の集合体として 表現するシステムである. そのシステムでは, 色やトポロジーデータなどを表現できない. またカーブ形状などの表現も行うことが出来 ない. しかしデータ構造が簡単であることか らラピッドプロトタイピングの分野では標準フ オーマットとなっている.

オブジェクトの形状は, 三つの頂点の座
標と法線ベクトルにより定義される三角形ポ リゴンであるファセットの集合により表現する. stl形式では, ASCII STL形式と,バイナリ STL形式があるが, 今回使用したASCII形式 について述べる.

ASCII STL形式では, 最初の行は以下の 文で始まる.

solid name

nameはオプションである.

このあとに次に示す三角形データが続

$<$.

facet normal ni nj nk outer loop vertex v1x v1y v1z vertex v2x v2y v2z vertex v3x v3y v3z endloop endfacet

5 3Dプリンタ

3Dプリンタは, uPrint SEである. モデル 材は, ABSplus 熱可塑性プラスチックを使 用している.ABSplusは, サポート材は， SR-30 可溶性である. 造形エリア $(\mathrm{X} \times \mathrm{Y}$ × Z)は, $203 \times 152 \times 152 \mathrm{~mm}$ で, 積層 ピッチは, $0.254 \mathrm{~mm}$ である.

3Dプリンタは, STL形式を受け取れるが, このプリンタでは, ソフトであるCatalystEX が, STL形式から印刷データに変換する.

\section{6 試作について}

作業の流れは次のようになる.

$3600 \times 3600$ 画素, 16 ビットのTIFF画像か ら, 世界遺産に必要な部分を抽出する.

そして, 3Dプリンタで出力する. 


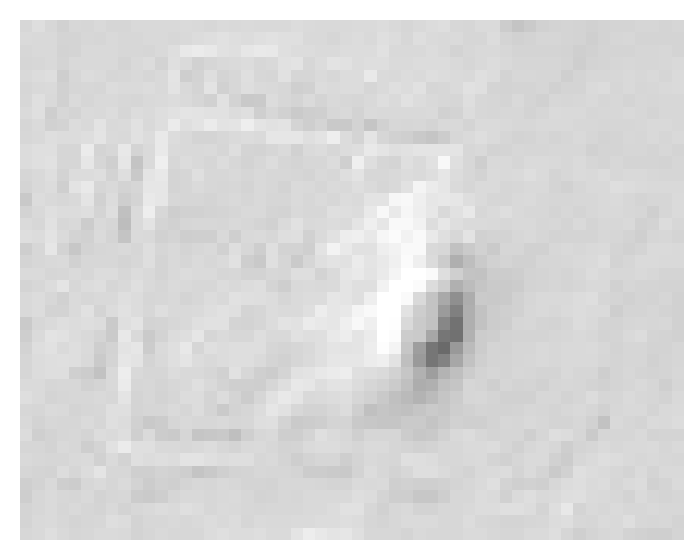

図 1 抽出された世界遺産

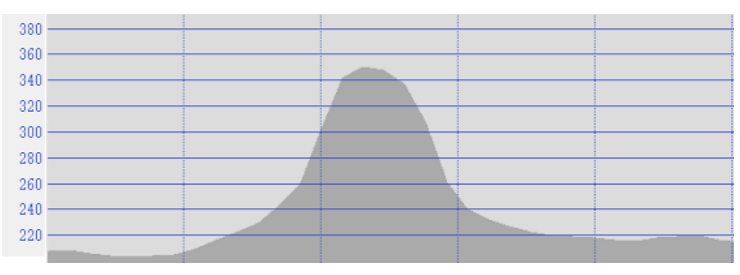

\section{図 2 南北に区切った世界遺産の高さ}

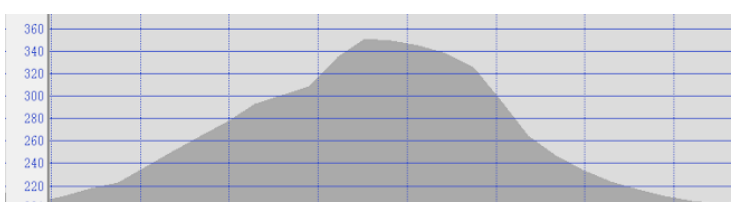

\section{図 3 東西に区切った世界遺産の高さ}

図 1 に抽出した画像を示す.

図 2 と図 3 に, シーギリヤ・ロックの断面図 を示す。

GeoTIFF画像の形式のこのデータは, 画 面上では2D画像に見えるが, 図 2 と図 3 に あるように高さを持つためにSTLデータに変 換できる.

そして, 抽出した画像をSTLデータに変 換し, 3Dプリンタで印刷出力した.

\section{7 考察}

このように地理空間情報を利用すると，
色々と便利なことが出来る.

しかし, 一般の人が，日本以外の画像を 自在に扱って 3Dプリンタに出力することが どうなるのか. スリランカの法律がそれを禁じ たらどうなるのか.

3Dデータのファイルは空間情報基盤と して位置付けられており, GISやCADなどの アプリケーションで利用するにあたっては， 各アプリケーションが必要とする分類や構造 への加工や属性の追加が必要となる.

$$
\text { そのため, 3Dデータは標準化された分類 }
$$
と単純なデータタイプ, 加工しやすい構造と なっている. 3DデータのファイルはGISアプ リケーション等で表示させるが, そのまま読 み込み表示できるアプリケーションは少な い.

今回には, 画像データ, 3 次元データ, そ して3Dプリンタの出カファイルに変換した.

国土地理院では, 主に地方公共団体に対 し, 地域に密着した詳細な地理情報である 3Dデータのファイルを誰もが利活用できる よう電子国土の背景データとして発信するよ う呼びかけがされている.

互換性の問題を低減するためのサブセッ トが提案されるが，必ずしもその基準は守ら れない.

\section{8 まとめ}

スリランカにある世界遺産シーギリヤにつ いて, ALOSグローバルデジタルサーフェス モデルを使用して 3Dプリンタで印刷した.

\section{参考文献}

［1］宇宙航空研究開発機構 地球観測研 究センター：「ALOS全球数值地表モデル (DSM) "ALOS World 3D - 30m"」, 2015. 
情報知識学会誌 2017 Vol.27, No. 2 